\title{
Areas of the Administration System Improvement of the Unified Contribution to Compulsory State Social Insurance
}

\author{
LESIA MARUSHCHAK ${ }^{1}$, OLHA PAVLYKIVSKA ${ }^{1}$, IRYNA LAHUTINA ${ }^{2}$, VALENTYNA BORKOVSKA ${ }^{3}$, \\ OLENA PRYGODIUK ${ }^{4}$, INNA BITIUK ${ }^{4}$ \\ ${ }^{1}$ Department of the Accounting and Audit, TERNOPIL IVAN PULUJ NATIONAL TECHNICAL UNIVERSITY, UKRAINE, \\ E-mail: lesiamar@tutanota.com \\ 2Department of Labour Law and Social Security Law, NATIONAL UNIVERSITY "ODESSA LAW ACADEMY", \\ UKRAINE \\ ${ }^{3}$ Department of Accounting, Taxation and E-Business Technologies, STATE AGRARIAN AND ENGINEERING \\ UNIVERSITY IN PODILIA, UKRAINE \\ ${ }^{4}$ Department of Management and Business Administration, CHERKASY STATE TECHNOLOGICAL UNIVERSITY, \\ UKRAINE
}

\begin{abstract}
The research was pointed out the effectiveness of the unified social contribution model in contrast to the financial amount collected to the Pension Fund and debts raised from the unsteady proportion of tax burden on different types of business. A practice that was analyzed in research has shown that this insurance model was not suitable for many companies and employees. Thus, the diagnostics of calculating the unified contribution debt results according to the current legislation proved low efficiency of the current procedure, which requires further improvement both in the legislative and executive planes. As an improvement of this theoretical background, it could point to the number of debts and quantities of claims brought to the economic entities and entrepreneurs. It is crucial to adopt international experience to create an effective internal system for tax collection, so we aimed to shed light on this problem of the tax burden faced by businesses and households by comparing them with similarly constructed taxes in European countries.
\end{abstract}

Keywords: taxation, social benefits, budget, salary.

JEL Classification: D31, E24, H21, J39 


\section{Introduction.}

All economic entities in Ukraine, regardless of their form of ownership, should make accruals of contributions to compulsory state social insurance to the payroll fund for the employees working under the terms of employment and civil contracts. Employers must report on the unified contribution (UC) of the employees monthly to the fiscal authorities. Constant changes in the normative and legal framework regarding accrual, payment, and declaration of the UC require a modern accountant to make timely clarifications both in the procedure of their accounting and when displaying information about such calculations in the enterprise reports. An important place in the UC reporting system belongs to the consistency of indicators concerning the EU's accruals withdrawn from the salary, temporary disability benefits, maternity benefits, transitional leave allowances, etc.

The introduction of the UC has helped simplify the relations of its payers with the state, facilitate the procedure of collection and administration, and increase insurance funds' income. The primary task in developing the economic system is selecting and complying with the optimal tax policy. This process is related to balancing the tax burden on business entities and performing the state's social functions. That is because excessive tax burden causes a decrease in the profitability of taxpayers' activities, tax evasion, and their possible bankruptcy and liquidation.

The national economy's critical problem is bringing the business into the shadow and refusal to create new business structures. A large part of the revenues from the total amount of taxes and charges includes social insurance contributions not only for entrepreneurs but also for employees. Therefore, introducing any changes to the UC tax framework for entrepreneurs immediately significantly impacts the entrepreneur's expenses on paying tax liabilities.

\section{Literature Review.}

During the whole period of Ukrainian independence, the taxation system was imperfect. Many authors stressed that Ukraine's taxation system needs to be deeply reformed, and significant tax structure changes must be taken (Prokopenko et al., 2019; Zakharkin et al., 2019). The vertical transfers system should be limited to the amounts of benefits granted under the insurance contributions. Instead, the current pension system produces a significant burden on the state budget (Sidelnykova, 2016). The introduction of the unified gift was intended to ensure the complete and continuous flow of funds into the accounts of all four social funds, reduce the administrative and financial burden on employers and simplify reporting for business entities (Kiselyova, 2020; Žul'ová \& Kundrát, 2020).

Among numerous maladjustments, the principles of co-operation of both institutions of authority must be improved regarding organizational and economic questions related to particular problems: local self-government functions and insufficient level of their financial provision (Liakhovych, 2019). The Government proposed a mechanism for reducing this type of tax. However, this mechanism is not transparent. It contains several issues for practical calculation and a reduced size tax. Consequently, the problem of controlling the correct accrual and payment at different rates and methods of accounting in the transitional period is exacerbated (Kozir, Tyvaniuk, 2015). These authors also stress that it is necessary to reduce tax and make it more flexible for the different business groups (Kwilinski et al., 2019; Czyżewski et al., 2019).

The introduction of impressive reliefs for small businesses is often based on vital political considerations. Business lobby groups are vociferous. Although small companies have less economic power than large companies, experience suggests that the small business community can be evident and often championed by the media. The result can be the introduction of reliefs, which become entrenched into the system and are hard to remove even if found to be unhelpful (11 Small Business Taxation). However, the experience with the abolition of the nil rate of tax in the UK does show that business will broadly support simplifying measures where the reliefs have become very complex (Crawford, 2011). 
The extent to which taxes affect employees' payor wages depends on the types and nature of taxes and their rates. The increase in tax rates off-set the annual increase in employee salaries, diminishing the annual increase by the value of the tax rate applied. It means that if the yearly growth is lower than the tax rate increase, the gross income will increase, but the personal income earned or after-tax income will diminish. To off-set the rise in prices of goods and services because of the increase in the rate of taxes, the employees expect higher wages or pay from their employer (Sanaullah, 2017). Therefore, employees look for jobs that give them better compensation for the rise in taxes. In this competitive market, employers increase skilled employees' pay to compensate them against rising taxes and retaining these skilled workers (McGuigan, 2015). It is so essential to correct tax influence on the medium and small sizes business. Adjustment of the single social tax based on the simplified taxation system for payers will allow staying competitive on the market and reducing the shade business (Makarenko, 2017).

International practice is a considerable possibility to reform the tax system in Ukraine. Europe has a flexible tax burden across its countries to create an appropriate single social tax model for the national economy (Wolff, 2005). Tax systems directly influence economic growth and negative impact during the financial crisis and instability on small and medium businesses (Zipfel, 2012). It is useful to stress that OECD (the Organisation for Economic Co-operation and Development) made a significant contribution to creating the base research source of the taxation system in Europe for users of information. Similar taxation systems are adopted in the USA and Germany (Lorenz et al., 2017), who proved that tax components depend on sizable business sectors.

\section{Method.}

As the article deals with the general principles of calculation and payment of the unified social tax in Ukraine, amounts of collected financial recourses, and debts raised from the ineffective distribution method, there were used alternative and comparative types of analysis. The connection between exploratory units is unclear entirely, so the additional techniques that help to detail each separate unit component were correlation and systematic studies. The system-structural method made it possible to investigate legal issues that regulate unified social tax in Ukraine. The research methodology is grounded on the inductive approach to get conclusions based on statistic figures and facts. The study's empirical basis is the generalized practice, tax date figures, administration activities, statistics, and other materials, publications in the press. There were also accounts used such methods: abstract-logical at generalizations and monographic at presentation.

\section{Results.}

The UC introduction's primary purpose was to consolidate the funds' activities in terms of the distribution of social insurance and pension insurance contributions. The introduction of the contribution was intended to replenish the Pension Fund's budget and resolve the state's pension provision. The unified contribution to the compulsory state social insurance is a consolidated insurance contribution collected into the mandatory state social insurance system on a mandatory and regular basis to protect insured persons' rights to receive insurance payments. Ultimately, people receive insurance payments within the existing compulsory social state insurance types. However, in practice, many changes have been made within the UC administration system, which indicates the imperfection of the current framework. Given that the design of administration of a unified contribution to compulsory state social insurance plays a significant role in financing the social sphere of Ukraine, the national social protection system's effectiveness largely depends on the timely receipt of insurance contributions.

What concerns the contribution rate since January 2016, the UC's basic rate has been $22 \%$ (previously it was $34.7 \%$ ). Also, there are reduced rates for specific population categories, particularly for workers with disabilities. The UC rate is $8.41 \%$ of the salary. There are special UC rates set for enterprises and non-governmental organizations of disabled people $-5.5 \%$. If the organization with 
disabilities has an all-Ukrainian status, its rate is 5.3\% (Konovalova, 2019). UC revenues' positive dynamics should be indicated, particularly in 2018 - 228024.9 million UAH and 180805.2 million UAH in 2017. On September $1^{\text {st }}, 2019$, the UC's payment revenues accrued nearly 176549.2 million UAH. Detailed information on the UC revenues is provided in Table 1 (State fiscal service of Ukraine).

Table 1. The analysis of revenues of the unified contribution to compulsory state social insurance in Ukraine

\begin{tabular}{|c|c|c|}
\hline Reporting period & The amount of revenue ths. UAH. & $\begin{array}{c}\text { Deviations of revenues (of the amount } \\
\text { of the previous year) }\end{array}$ \\
\hline 01.01 .2019 & 228024.90 & 47219.70 \\
\hline 01.01 .2018 & 180805.20 & 48978.50 \\
\hline 01.01 .2017 & 131826.70 & -53863.20 \\
\hline 01.01 .2016 & 185689.90 & 4561.90 \\
\hline 01.01 .2015 & 181128.00 & \\
\hline
\end{tabular}

Source: Formed based on the State Fiscal Service of Ukraine data (2019).

Table 2. Dynamics of the arrears under the unified contribution to compulsory state social insurance

\begin{tabular}{|c|c|c|c|c|c|c|c|}
\hline $\begin{array}{l}\text { Region } \\
\text { code }\end{array}$ & $\begin{array}{l}\text { Name of the } \\
\text { region }\end{array}$ & 01.04 .2019 & 01.01 .2019 & 01.01 .2018 & 01.01 .2017 & 01.01 .2016 & $\begin{array}{c}\begin{array}{c}\text { Deviations } \\
\text { from }\end{array} \\
01.04 .2019 \\
\text { to } \\
01.01 .2016\end{array}$ \\
\hline 1 & $\begin{array}{l}\text { The Autonomous } \\
\text { Republic of } \\
\text { Crimea }\end{array}$ & 195162.9 & 195307.7 & 179787.5 & 181567.8 & 180480.1 & 14682.8 \\
\hline 2 & Vinnytsia & 255183.0 & 239852.6 & 58419.0 & 75414.6 & 72166.2 & 183016.8 \\
\hline 3 & Volyn & 340334.8 & 321020.6 & 176016.8 & 116512.6 & 111296.3 & 229038.5 \\
\hline 4 & Dnipropetrovsk & 885051.4 & 819896.5 & 237744.8 & 205064.4 & 227847.4 & 657204.0 \\
\hline 5 & Donetsk & 4370518.3 & 4331826.3 & 2782615.0 & 2314081.3 & 2284728.3 & 2085790.0 \\
\hline 6 & Zhytomyr & 240911.1 & 226447.7 & 99114.6 & 100585.6 & 97611.2 & 143299.9 \\
\hline 7 & Zakarpattia & 201115.9 & 196723.7 & 35580.5 & 32065.1 & 30774.2 & 170341.7 \\
\hline 8 & Zaporizhzhia & 466509.0 & 443103.7 & 82566.3 & 99542.4 & 98179.7 & 368329.3 \\
\hline 9 & Ivano-Frankivsk & 160354.4 & 155348.6 & 46334.7 & 46301.5 & 45957.4 & 114397.0 \\
\hline 10 & Kyiv & 511560.1 & 484287.4 & 168242.5 & 196219.0 & 173251.7 & 338308.4 \\
\hline 11 & Kirovohrad & 183761.9 & 162932.2 & 48489.6 & 47148.2 & 42945.9 & 140816.0 \\
\hline 12 & Luhansk & 1720906.3 & 1610137.7 & 1117102.5 & 1002784.4 & 923421.1 & 797485.2 \\
\hline 13 & Lviv & 736383.9 & 761229.5 & 402303.9 & 324966.0 & 332481.7 & 403902.2 \\
\hline 14 & Mykolaiv & 390488.8 & 365889.6 & 171557.5 & 149576.7 & 134494.5 & 255994.3 \\
\hline 15 & Odesa & 683380.9 & 615006.9 & 140618.6 & 139636.5 & 131315.9 & 552065.0 \\
\hline 16 & Poltava & 212533.7 & 201305.1 & 80132.9 & 72580.4 & 69315.2 & 143218.5 \\
\hline 17 & Rivne & 133392.2 & 115884.8 & 50537.3 & 44868.3 & 47806.4 & 85585.8 \\
\hline 18 & Sumy & 156081.7 & 148661.7 & 63523.4 & 59170.6 & 57562.8 & 98518.9 \\
\hline 19 & Ternopil & 93695.4 & 90550.6 & 21150.5 & 20710.4 & 19542.7 & 74152.7 \\
\hline 20 & Kharkiv & 811703.7 & 751235.4 & 207182.0 & 204016.3 & 196931.6 & 614772.1 \\
\hline 21 & Kherson & 292059.5 & 277518.7 & 77135.9 & 40818.6 & 38946.0 & 253113.5 \\
\hline 22 & Khmelnytskyi & 150154.7 & 145206.5 & 49388.1 & 53403.3 & 52664.1 & 97490.6 \\
\hline 23 & Cherkasy & 190417.4 & 182045.8 & 66632.3 & 64213.2 & 62218.7 & 128198.7 \\
\hline 24 & Chernivtsi & 204417.1 & 194226.8 & 36199.2 & 40043.1 & 35658.5 & 168758.6 \\
\hline 25 & Chernihiv & 175579.7 & 160034.1 & 61572.9 & 53383.5 & 49276.7 & 126303.0 \\
\hline 26 & The city of Kyiv & 1531984.4 & 1465964.4 & 696145.7 & 643513.1 & 583448.5 & 948535.9 \\
\hline 27 & $\begin{array}{l}\text { The city of } \\
\text { Sevastopol }\end{array}$ & 56087.5 & 56118.0 & 56171.6 & 33244.7 & 33319.6 & 22767.9 \\
\hline 28 & $\begin{array}{l}\text { Large Taxpayers } \\
\text { Office of the } \\
\text { State Tax } \\
\text { Service of } \\
\text { Ukraine }\end{array}$ & 597174.4 & 501917.7 & 460931.2 & 538966.0 & 461003.8 & 1361706 \\
\hline \multicolumn{2}{|l|}{ TOTAL: } & 15946904.0 & 15219680.4 & 7673196.8 & 6900397.5 & 6594646.2 & 9352257.8 \\
\hline
\end{tabular}

Source: The letter of the State Fiscal Service of Ukraine (2019). 
The largest share in the structure of the unified contribution revenues was the amount accrued by employers for the number of wages, benefits under civil contracts, temporary disability benefits, maternity benefits, in particular, they constituted $87.6 \%$ (93336.9 million UAH).

Although in Article 67 of the Constitution of Ukraine (1996) was provided that everyone is obliged to pay taxes and charges under the procedure and in the amount prescribed by law. Nevertheless, nowadays, not all business entities solemnly pay the unified contribution that violates the norms of the current legislation in the country and the basics of social security for insured citizens. Thus, on January $1^{\text {st }} 2019$, Ukraine's unified contribution payment debt amounted to 15219.6 million UAH. On April $1^{\text {st }} 2019$, this debt amounted to 15946.9 million UAH based on the first-quarter results. It exceeded the amount displayed on January $1^{\text {st }}$ of the current year by 727.3 million UAH (Table 2).

Table 3. Information of the STS regarding claims directed to the State Executive Service on the UC debt payment (arrears)

\begin{tabular}{|c|c|c|c|c|c|c|c|c|c|c|c|}
\hline $\begin{array}{l}\text { Region } \\
\text { code }\end{array}$ & $\begin{array}{l}\text { Name of the } \\
\text { region }\end{array}$ & \multicolumn{2}{|c|}{01.01 .2019} & \multicolumn{2}{|c|}{01.01 .2018} & \multicolumn{2}{|c|}{01.01 .2017} & \multicolumn{2}{|c|}{$\begin{array}{c}\text { Deviations from } \\
01.01 .2019 \text { to } \\
01.01 .2017\end{array}$} & \multicolumn{2}{|c|}{01.04 .2019} \\
\hline 1 & $\begin{array}{l}\text { Autonomous } \\
\text { Republic of } \\
\text { Crimea }\end{array}$ & 0 & 0.0 & 0 & 0.0 & 0 & 0.0 & 0 & 0.0 & 0 & 0.0 \\
\hline 2 & Vinnytsia & 7168 & 69315.8 & 3812 & 25805.7 & 3725 & 37187.8 & 3443 & 32128.0 & 7147 & 91936.8 \\
\hline 3 & Volyn & 1932 & 196131.3 & 1168 & 33809.2 & 1543 & 44513.6 & 389 & 151617.7 & 2957 & 61919.8 \\
\hline 4 & $\begin{array}{l}\text { Dnipropetrovs } \\
\mathrm{k}\end{array}$ & 8782 & 132817.3 & 7412 & 111583.5 & 13359 & 164268.2 & -4577 & -31450.9 & 2785 & 62832.6 \\
\hline 5 & Donetsk & 4358 & 1107749.9 & 1835 & 432352.8 & 3195 & 492384.4 & 1163 & 615365.5 & 2365 & 128209.3 \\
\hline 6 & Zhytomyr & 1965 & 27724.3 & 1204 & 14511.5 & 2698 & 43954.0 & -733 & -16229.7 & 2168 & 34855.9 \\
\hline 7 & Zakarpattia & 2597 & 18532.3 & 2241 & 19010.7 & 4092 & 21238.6 & -1495 & -2706.3 & 4276 & 57558.4 \\
\hline 8 & Zaporizhzhia & 8124 & 151365.1 & 3614 & 31722.4 & 3766 & 40767.6 & 4358 & 110597.5 & 4611 & 67776.5 \\
\hline 9 & $\begin{array}{l}\text { Ivano- } \\
\text { Frankivsk }\end{array}$ & 4647 & 48941.3 & 1997 & 17615.3 & 2452 & 22102.4 & 2195 & 26838.9 & 2487 & 28129.7 \\
\hline 10 & Kyiv & 5650 & 104958.7 & 1885 & 44358.1 & 2693 & 51824.3 & 2957 & 53134.4 & 11221 & 230851.4 \\
\hline 11 & Kirovohrad & 1414 & 35449.7 & 578 & 15733.9 & 1961 & 35670.5 & -547 & -220.8 & 2859 & 46801.5 \\
\hline 12 & Luhansk & 1037 & 208264.8 & 527 & 177155.9 & 907 & 177958.7 & 130 & 30306.1 & 644 & 38627.8 \\
\hline 13 & Lviv & 4885 & 393462.2 & 1878 & 241805.8 & 3063 & 269689.1 & 1822 & 123773.1 & 1259 & 144021.4 \\
\hline 14 & Mykolaiv & 2398 & 61900.6 & 1143 & 49599.3 & 2899 & 54082.0 & -501 & 7818.6 & 700 & 14506.7 \\
\hline 15 & Odesa & 7242 & 85147.2 & 3768 & 41107.8 & 5038 & 38255.2 & 2204 & 46892.0 & 2667 & 43638.1 \\
\hline 16 & Poltava & 3937 & 32534.2 & 3435 & 19992.6 & 4463 & 22335.6 & -526 & 10198.6 & 2972 & 38996.5 \\
\hline 17 & Rivne & 3575 & 55344.1 & 1915 & 9875.6 & 1693 & 22425.1 & 1882 & 32919.0 & 1310 & 27273.1 \\
\hline 18 & Sumy & 1549 & 45012.6 & 817 & 22539.2 & 1298 & 43341.1 & 251 & 1671.5 & 2359 & 36227.6 \\
\hline 19 & Ternopil & 2109 & 19116.6 & 558 & 2616.0 & 1789 & 10387.6 & 320 & 8729.0 & 1750 & 22001.4 \\
\hline 20 & Kharkiv & 4628 & 155946.1 & 5058 & 82103.9 & 4243 & 130619.4 & 385 & 25326.7 & 5582 & 87337.2 \\
\hline 21 & Kherson & 2643 & 72162.1 & 398 & 37709.6 & 676 & 50556.9 & 1967 & 21605.2 & 1833 & 33105.3 \\
\hline 22 & Khmelnytskyi & 4834 & 39734.9 & 2723 & 20801.6 & 2844 & 21937.0 & 1990 & 17797.9 & 2723 & 39098.6 \\
\hline 23 & Cherkasy & 3890 & 53052.0 & 2423 & 38861.8 & 3401 & 28164.2 & 489 & 24887.8 & 8230 & 50579.8 \\
\hline 24 & Chernivtsi & 2635 & 39785.6 & 1087 & 12589.9 & 1615 & 17181.4 & 1020 & 22604.2 & 1958 & 36201.4 \\
\hline 25 & Chernihiv & 1301 & 28187.2 & 1197 & 14242.5 & 2081 & 31116.1 & -780 & -2928.9 & 1075 & 18689.7 \\
\hline 26 & $\begin{array}{l}\text { The city of } \\
\text { Kyiv }\end{array}$ & 8164 & 382490.3 & 3775 & 342969.4 & 2694 & 584263.6 & 5470 & -201773.3 & 830 & 29674.2 \\
\hline 27 & $\begin{array}{l}\text { The city of } \\
\text { Sevastopol }\end{array}$ & 0 & 0.0 & 0 & 0.0 & 0 & 0.0 & 0 & 0.0 & 0 & 0.0 \\
\hline 28 & $\begin{array}{l}\text { Large } \\
\text { Taxpayers } \\
\text { Office of the } \\
\text { State Tax } \\
\text { Service of } \\
\text { Ukraine }\end{array}$ & 35 & 342204.1 & 47 & 176786.9 & 52 & 809524.6 & -17 & -467320.5 & 10 & 64430.1 \\
\hline & OTAL: & 101499 & 3907330.0 & 56495 & 2037260.8 & 78240 & 3265748.9 & 23259 & 641581.1 & 78778 & 1535280.7 \\
\hline
\end{tabular}

Source: The letter of the State Fiscal Service of Ukraine (2019).

Analyzing the dynamics of the UC arrears growth, we should highlight its regularities: a sharp increase in 2017-2018 due to the change of legislative norms on the procedure for the UC accrual for the so-called 'sleeping business entities', it was concerned to persons who once completed 
registration as business entities, but have not performed it, and did not take action to terminate such registration by January $1^{\text {st }} 2017$.

Attention should be paid to the requirements for the payers to comply with the deadlines for the UC payment since the bodies of the State Tax Service (from now on referred to as the "STS") take measures to recover such debt from the payers who have not fulfilled the statutory obligations for timely accrual, calculation and payment of the unified contribution. One of the effective measures in this process is the formation of claims indicating the need to contribute. Analyzing the number and dynamics of the unified contribution claims directed to the Enforcement Service bodies by the current normative and legal acts, it is necessary to note the negative dynamics of increasing in both the number of debtors and the amounts of debt (Table 3 ).

At the same time, the indication should be made about the consequences of the fiscal authorities' actions concerning the debtors who were charged by the SES bodies to recover the arrears, which is shown in Table 4.

Table 4. Dynamics of amounts recovered by the SES towards debt repayment by regions of Ukraine

\begin{tabular}{|c|c|c|c|c|c|c|}
\hline $\begin{array}{l}\text { Region } \\
\text { code }\end{array}$ & $\begin{array}{l}\text { Name of the } \\
\text { region }\end{array}$ & 01.01 .2019 & 01.01 .2018 & 01.01 .2017 & $\begin{array}{c}\begin{array}{c}\text { Deviations } \\
\text { from }\end{array} \\
01.01 .2019 \\
\text { to } \\
01.01 .2017\end{array}$ & 01.04 .2019 \\
\hline 1 & 2 & 4 & 5 & 6 & 7 & 3 \\
\hline 1 & $\begin{array}{l}\text { The } \\
\text { Autonomous } \\
\text { Republic of } \\
\text { Crimea }\end{array}$ & 0.0 & 0.0 & 0.0 & 0.0 & 0.0 \\
\hline 2 & Vinnytsia & 11096.4 & 5669.9 & 7054.5 & 4041.9 & 7173.6 \\
\hline 3 & Volyn & 6888.4 & 3261.9 & 2078.9 & 4809.5 & 374.2 \\
\hline 4 & Dnipropetrovsk & 25534.4 & 23849.0 & 29911.8 & -4377.4 & 8996.0 \\
\hline 5 & Donetsk & 3078.0 & 2182.3 & 1171.4 & 1906.6 & 984.3 \\
\hline 6 & Zhytomyr & 6049.9 & 3834.0 & 6456.0 & -406.1 & 3206.0 \\
\hline 7 & Zakarpattia & 3758.9 & 1867.3 & 6522.8 & -2763.9 & 3271.7 \\
\hline 8 & Zaporizhzhia & 10617.4 & 6430.7 & 13718.0 & -3100.6 & 5927.4 \\
\hline 9 & Ivano-Frankivsk & 7271.1 & 7930.5 & 5143.7 & 2127.4 & 5180.9 \\
\hline 10 & Kyiv & 12121.9 & 2911.5 & 4308.6 & 7813.3 & 6383.4 \\
\hline 11 & Kirovohrad & 15495.8 & 12030.4 & 13646.8 & 1849.0 & 3459.2 \\
\hline 12 & Luhansk & 3407.6 & 2403.9 & 3276.4 & 131.2 & 1491.3 \\
\hline 13 & Lviv & 21448.7 & 8785.6 & 11518.0 & 9930.7 & 4799.0 \\
\hline 14 & Mykolaiv & 4923.2 & 7555.5 & 7907.2 & -2984.0 & 910.5 \\
\hline 15 & Odesa & 6187.4 & 3300.9 & 4007.6 & 2179.8 & 2629.6 \\
\hline 16 & Poltava & 5265.3 & 2866.7 & 5281.4 & -16.1 & 2152.4 \\
\hline 17 & Rivne & 1696.2 & 1956.7 & 3209.7 & -1513.5 & 367.8 \\
\hline 18 & Sumy & 2835.0 & 4859.1 & 3174.8 & -339.8 & 987.7 \\
\hline 19 & Ternopil & 5236.9 & 4286.4 & 4130.7 & 1106.2 & 2813.4 \\
\hline 20 & Kharkiv & 24251.2 & 13148.8 & 22593.0 & 1658.2 & 13915.4 \\
\hline 21 & Kherson & 19597.2 & 11964.2 & 28313.2 & -8716.0 & 138.5 \\
\hline 22 & Khmelnytskyi & 4697.1 & 2404.3 & 3279.7 & 1417.4 & 3832.7 \\
\hline 23 & Cherkasy & 4348.0 & 6182.3 & 2887.8 & 1460.2 & 2888.7 \\
\hline 24 & Chernivtsi & 17781.2 & 4350.2 & 9345.2 & 8436.0 & 7582.0 \\
\hline 25 & Chernihiv & 10077.1 & 2297.9 & 6498.7 & 3578.4 & 578.6 \\
\hline 26 & The city of Kyiv & 78042.8 & 35085.4 & 15836.7 & 62206.1 & 23529.5 \\
\hline 27 & $\begin{array}{l}\text { The city of } \\
\text { Sevastopol }\end{array}$ & 0.0 & 0.0 & 0.0 & 0.0 & 0.0 \\
\hline 28 & $\begin{array}{l}\text { Large } \\
\text { Taxpayers } \\
\text { Office of the } \\
\text { State Tax } \\
\text { Service of } \\
\text { Ukraine }\end{array}$ & 7385.6 & 1167.1 & 6620.2 & 765.4 & 0.0 \\
\hline & TOTAL: & 319092.7 & 182582.4 & 227892.80 & 91199.9 & 113573.8 \\
\hline
\end{tabular}

Source: The letter of the State Fiscal Service of Ukraine (2019). 
It is appropriate to pay attention to the fact that the state takes measures to recover such arrears at the expense of the state resources, which are ineffective and can also be considered wasteful. For example, just one fact is worth mentioning: the amount required to send the claim for debt payment is $10 \mathrm{UAH}$ at present, and the cost of the registered mail item is $31 \mathrm{UAH}$ (excluding the cost of an envelope, the paper used, and working time spent on it). In this case, the actual cost of notifying the debtor that they have arrears exceeds the recovery's cost-effectiveness by more than three times without considering the associated costs. Moreover, although the UC is of great social importance, such expenditures' practicality without their economic expediency is unacceptable. Extra $21 \mathrm{UAH}$ is taken out of the taxpayers' pocket, which could be spent on other purposes, including the social expenditures mentioned. This problem became significant on a state-wide scale and required state funds excess expenditure.

Another imperfect framework is the mechanism of claim form, which involves forming a recurrent claim both in case of the arrear increased and its appearance and sending it to the payer in the event of a decrease in such arrears.

At the same time, attention should be given to the reason for such a waste of state resources. It is incredibly the cost of a registered mail item with a delivery notice as required by law, particularly the change in their cost year-wise, as shown in Table 5.

There is a necessity to use legislation that would consider the procedure for debt recovery. For this purpose, it is necessary to diagnose the maximum base of the UC accrual since 2018. The law regulates it at 15 minimum wages (55845 UAH). For example, if the above amount is exceeded, this contribution is not charged. Even the foreign experience was adopted, this procedure is unacceptable. The administration process should be based on a progressive scale of taxation of UC amounts above the maximum base. Compared to payments that were directed from UC amounts to retirement benefits in Ukraine at a flat rate of $22 \%$ with other countries, different indicators could be observed. For example, in Estonia, $22 \%$ is directed for this purpose. In Belarus, this number is $29 \%$. In Poland, it is $19.5 \%$. In the US, it is $15 \%$ (Konovalova, 2019).

Table 5. Change in the postage rates during the period from 2017 to 2019

\begin{tabular}{|c|c|c|c|c|}
\hline Year & Postage rate, UAH & $\begin{array}{c}\text { Cost growth } \\
\text { dynamics, UAH }\end{array}$ & $\begin{array}{c}\text { The minimum amount } \\
\text { of the claim, UAH }\end{array}$ & $\begin{array}{c}\text { Deviations of the } \\
\text { minimum amount of } \\
\text { the claim to the } \\
\text { postage rate }\end{array}$ \\
\hline 2019 & 31.0 & +22.5 & 10.0 & +21.0 \\
\hline 2018 & 23,0 & +14.5 & 10.0 & +13.0 \\
\hline 2017 & 16,0 & +7.5 & 10.0 & +6.0 \\
\hline 2016 & 12,0 & +3.5 & 10.0 & +2.0 \\
\hline 2015 & 8,5 & $X$ & 10.0 & $X$ \\
\hline
\end{tabular}

Source: Calculated by authors.

In addition to contributions made from payroll, in other countries, there are contributions to individual retirement savings accounts from which extra amounts are paid in addition to pensions. Moreover, in most countries with developed economies, low-wage citizens are exempt from income tax. However, the main burden of replenishing the state budget is upon the wealthy population for whom a progressive tax scale is set. It is important to note that those persons-entrepreneurs and farmers who receive a pension do not pay the UC. These citizens are exempted from paying their contribution because pension payments are part of retirement insurance and are therefore not included in the UC base. If the pensioners have received income from other activities, for example, according to the civil contracts, in this case, the deduction of the UC was made from income other than the pension, at the applicable UC rate.

It is worth noting that the current methodology is based on the following constituents of the UC in the budget: compulsory social unemployment insurance $(7.1767 \%)$, compulsory state temporary disability insurance $(7.726 \%)$, compulsory state retirement insurance $(78.5576 \%)$, and compulsory state social workplace accidents insurance (6.5397\%). In the study process, there was a significant conclusion that the UC cannot be canceled because it is the main constituent of the revenues to the Pension Fund of Ukraine. Moreover, as an improvement of this fact, the chairman of the Verkhovna 
Rada Committee of Finance, Taxation and Customs Policy D. Hetmantsev claimed that the council would not reduce the UC rates soon (Hetmantsev, 2019).

According to the data provided by the Ministry of Economic Development and Trade, the level of the shadow economy in Ukraine was $42 \%$ of GDP, and the annual amount of grey salaries was estimated at 175 billion UAH. Naturally, the budget received less than due of the proceeds from these revenues (the pension fund received less UC than due for 38.5 billion UAH) (Konovalova, 2019). The Government's priority is to unshadow income to create jobs and, as a consequence, to bring back labor migrants from abroad.

These are the reserves that will enable an increase in budget revenues at different levels. It is worth indicating that such taxes are in the other countries of Europe. This porpoise, Estonia spends $22 \%$, Belarus $-29 \%$, Poland $-19,5 \%$, USA $-15 \%$. Except for salaries, many special cumulative pension accounts are individual. They are used to paying an additional sum to pension.

For instance, the Polish social security system comprises three pillars that collect payments. Two are compulsory, and the third one is not. Contributions are divided between the employees and the employers. According to a Polish employment contract and Polish service contracts and business activities, social security is spread on income. It does not apply to foreign-sourced income unless EU regulations are applicable (Poland, KPMG). Now the social security contributions are made by both the employers and employees; however, in the employee's contributions, the employer makes the actual payment to the social security authorities (ZUS). Also, employers make payments toward the Labor Fund and the Employee's Guaranteed Benefits Fund, which is calculated on the individual's grossed-up salary. Polish tax similar to Ukrainian. The unified contribution is analyzed in Figure 1.

Figure 1. Type of insurance contribution in Poland

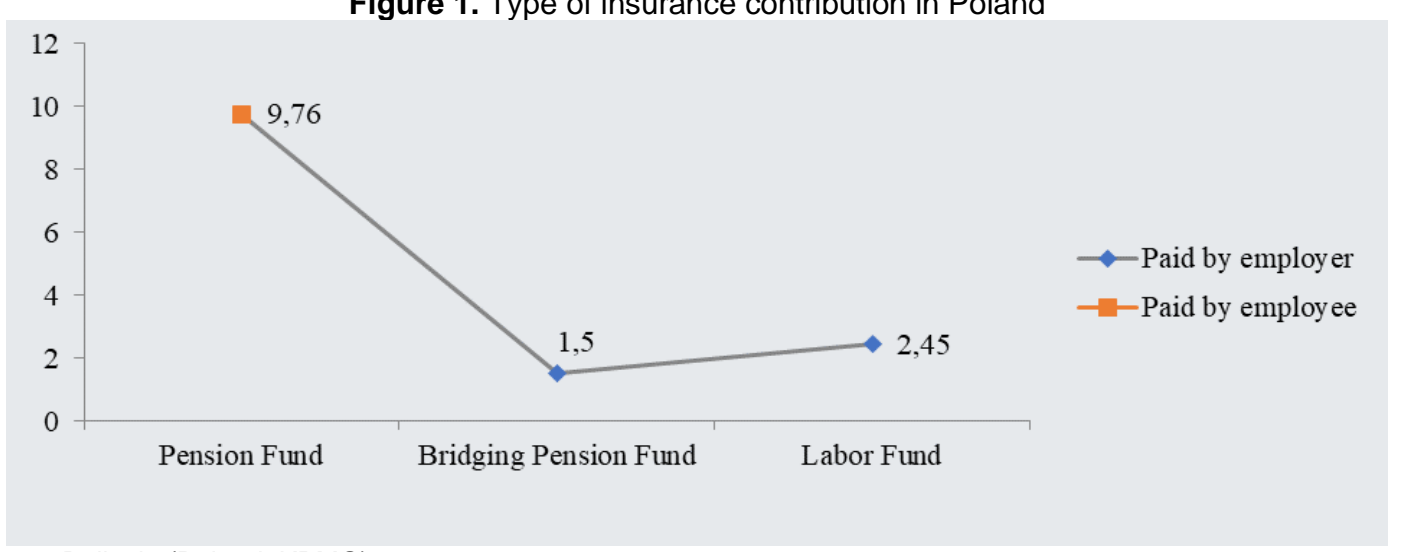

Source: Built via (Poland, KPMG).

Spain also has a similar insurance system. All employees who work in Spain have to be registered with the Spanish social security system, and the employers must bring the corresponding contribution for both employers and employees. It depends on each employee's category and cannot exceed certain limits. Employers and employees pay different sums $-29.90 \%$ and $6.35 \%$, respectively (Spain, KPMG).

A particular security system exists in Sweden. The country has one of the most highly developed welfare systems globally. Employers in Sweden have to pay Social Security contributions consisting of charges for pensions, health insurance, and other social benefits. The level of paying is different and depends on many factors. The amount is approximately $31.42 \%$ of the gross salary, where $10.21 \%$ represents pension contributions. Employees must pay $7 \%$ of their income to pension contributions, up to a maximum of SEK 29,400 a year. However, this contribution is neutralized by a corresponding income tax reduction for the employee (Table 6).

Greece's social security contributions system includes a $6.67 \%$ pension contribution plus $13.33 \%$ paid by the employer. 
Table 6. Level of tax for social security

\begin{tabular}{|c|c|}
\hline Ages & Level of tax for social security, \% (pension contribution) \\
\hline Under 26 & 15,49 \\
\hline Were born between 1938 to 1951 & 16,36 \\
\hline Were born in 1937 or earlier & 5,51 \\
\hline
\end{tabular}

Source: Calculated by authors via (Sweden, Global payroll).

Hungary's insurance system is not very different. The base for social security contribution is the gross income paid to the employee. The employer's contribution rate (social tax) is $17.5 \%$ from July 1st, 2019. The employees' contribution rate is $18.5 \%$ (Figure 2). The best insurance system is in the Czech Republic, where employers pay more than employees (Figure 3). A prerequisite for the growth of the welfare of the population and guarantees of its social protection is the timely payment of the unified contribution to compulsory state social insurance, which requires continuous compliance with the current legislation's requirements and improvement of the social standards the population as a whole.

\section{Discussion.}

The analysis discusses the importance of the unified contribution (tax) model adopted in Ukraine. This tax type is the specific insurance for many people who are obligated under Ukrainian law. This system has only several advantages and many disadvantages. The first advantage is the possibility for citizens to get confidence in the future pension providing. The second one is an available current source for the Ukrainian pension Fund. However, many problematic issues need scientific discussion and researches in the mentioned sphere. National scientists disagree that the accrual base is calculated from a minimum wage. In 2018 the minimum floor for tax accrual was 3723 hryvnias and the maximum - 55845 hryvnias.

Figure 2. The employees' contribution rate for personal insurance in Hungary, 2019 (Hungary, PWC)

The employees' contribution rate, \%, 2019

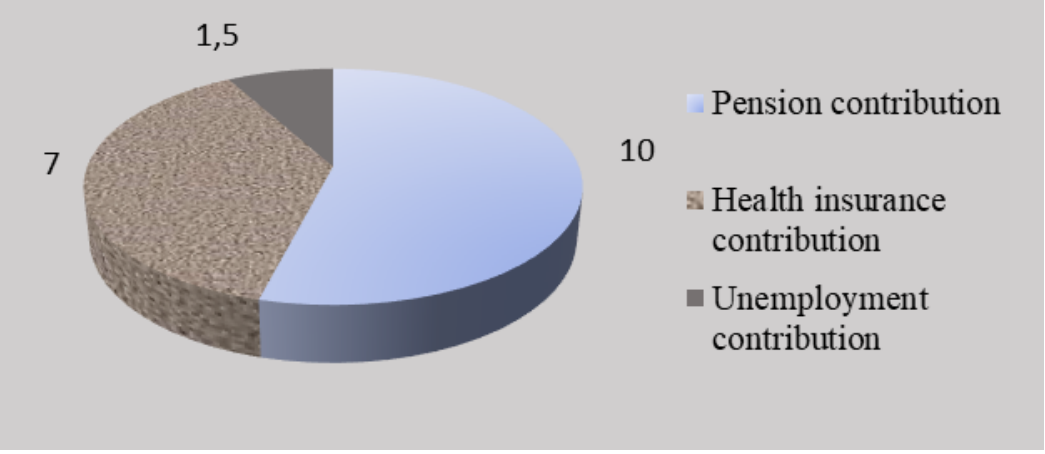

Figure 3. The insurance system in the Czech Republic, 2020 (Czech Republic, KPMG)

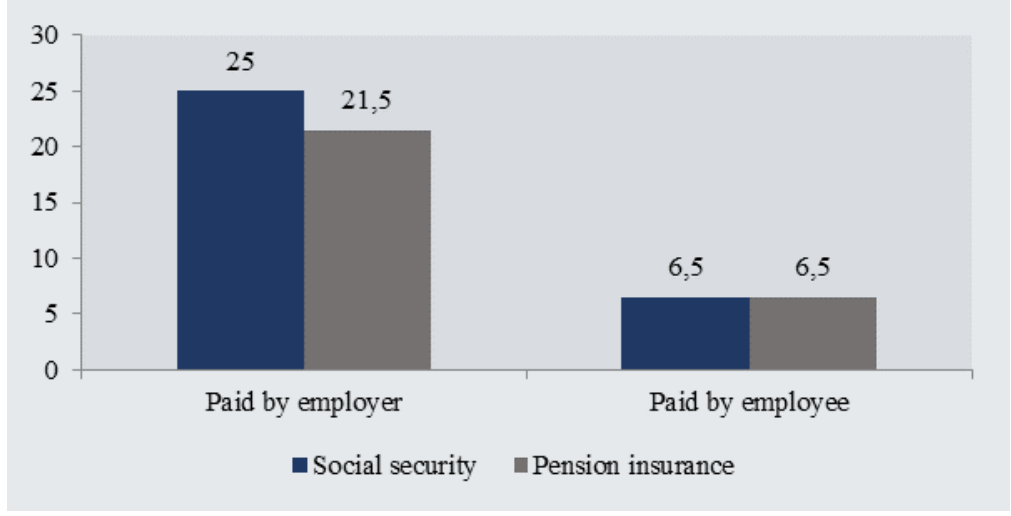


Nevertheless, if some entities do not get any profits, they are also obligated to pay the unified contribution. Authorities, politicians, and even deputies try to prove that business entities should not pay this tax type without profits. At the legislative level, there is a need for amendments in several normative legal acts that will enhance the administration process's improvement in all of its components. Concerning the UC administration, there is a need to improve the UC debt recovery methodology to avoid the excess expenditure of budgetary funds and enhance the UC claims formation framework. The suggested framework for managing the system of administration of the unified contribution to compulsory state social insurance based on a situational approach to regulating the tax system will improve it.

\section{Conclusion.}

Ukrainian Constitution guarantees the right for social protection to citizens that include providing them with financial support in the event of total, partial or temporary loss of working capacity, unemployment from independent circumstances, in old age, or other cases prescribed by the law. To simplify the tax burden, a unified contribution was adopted. Revenues from unified tax are not reflected in the State budget, and they are divided between the social insurance Funds. However, practice shows that this taxing unit is less effective than similar tax models in other countries.

There were adopted the minimum and maximum bases for accrual of the tax rate on the legal level, which depends on the minimum wage level. The dynamic of the unified contribution rate increases each year that causes many debts, especially for unprofitable business units, which are obligated to pay it. At this stage, it is recommended to create an algorithm for calculating an indicative rate of unified tax for different business units depending on their sizes and rates of profit. The law that regulates the administration, accrual and distribution of the unified tax also should be refined, especially in the case with unprofitable business units.

\section{References}

1. 11 Small Business Taxation Claire Crawford and Judith Freedman. https://studylib.net/doc/12811559/11-small-business-taxation-claire-crawford-and-judith-fre...

2. Crawford, C. \& Freedman, J. (2011). Small Business Taxation' in the Mirrlees review: reforming the tax systems for the 21th century, Oxford: Oxford university press for IFS, 2. https://www.ifs.org.uk/uploads/mirrleesreview/dimensions/ch11.pdf

3. Czech Republic - Other taxes and levies. KPMG. https://home.kpmg/xx/en/home/insights/2014/01/czech-republic-other-taxes-levies.html

4. Czyżewski, B., Matuszczak, A., \& Miśkiewicz, R. (2019). Public goods versus the farm price-cost squeeze: shaping the sustainability of the EU's common agricultural policy. Technological and Economic Development of Economy, 25(1), 82-102. https://doi.org/10.3846/tede.2019.7449

5. Hetmantsev, D. (2019). The Verkhovna Rada does not plan to reduce the UC rate and the burden on the wage bill. https://news.dtkt.ua/labor/social-protection/58129 [in Ukrainian]

6. Hungary. PWC. Retrieved from http://taxsummaries.pwc.com/ID/Hungary-Individual-Other-taxes

7. Kiselyova, E. (2020). Labor compliance as an instrument of labor relations control. Central European Journal of Labour Law and Personnel Management, 3 (1), 21-32. http://doi.org/10.33382/cejllpm.2020.04.02

8. Konovalova, Kh. (2019). Big showdown: what is UC and who needs it. https://ukr.segodnya.ua/economics/enews/bolshaya-razborka-chto-takoe-esv-i-komu-on-nuzhen1207138.html [in Ukrainian]

9. Kozir T.M., \& Tyvaniuk I.S. (2015). Reforming the single social contribution: problems and prospects. http://acadrev.duan.edu.ua/images/PDF/2015/1/9.pdf 
10. Kwilinski, A., Tkachenko, V., \& Kuzior, A. (2019). Transparent Cognitive Technologies to Ensure Sustainable Society Development. Journal of Security and Sustainability Issues, 9(2), 561-570 http://doi.org/10.9770/jssi.2019.9.2(15)

11. Liakhovych, G., Pavlykivska, O., Marushchak, L., Kilyar, O. \& Shpylyk, S. (2019). The organizationaleconomic aspects of land relations provision by administrative-territorial reform in Ukraine. Problems and Perspectives in Management, 17(2), 479-492. doi:10.21511/ppm.17(2).2019.37

12. Lorenz, J. Jarass, Anthony, E. Tokman, \& Mark, L. Wright. (2017). The burden of taxation in the United States and Germany. Chicago Fed Letter. file://C:/Users/Admin/Downloads/cfl382pdf.pdf

13. Makarenko, A. (2017). Assessment of the reforming of the unique social contribution in Ukraine. Economic science (Economic and state), 1, 15-18. [in Ukrainian]

14. McGuigan, M. (2015). How the introduction of tax would affect salaries in the UAE. Business. http://www.thenational.ae/business/economy/how-the-introduction-of-tax-would-affectsalaries-in-the-uae

15. Pavlykivska, O. \& Marushchak, L. (2019). Improvement Debt Refund Mechanism of the Unified Contribution to Compulsory State Social Insurance. Galician economik journal, 6 (61), 179-186. https://doi.org/10.33108/galicianvisnyk_tntu2019.06 [in Ukrainian]

16. Poland - Other taxes and levies. https://home.kpmg/xx/en/home/insights/2011/12/poland-other-taxes-levies.html

17. Prokopenko, O. et al. (2019). Methodology of national investment and innovation security analytics. Problems and Perspectives in Management, 17(1), 380-394. http://dx.doi.org/10.21511/ppm.17(1).2019.33

18. Sanaullah. (2017). A Review Paper on the Impact of Income Tax and Inflation on Salary. Asian Journal of Technology and Management Research, 07(01), 1-6.

19. Schneider F., Raczkowski K. \& Mróz B. (2015). Shadow economy and tax evasion in the EU. Journal of Money Laundering Control, 18 (1), 34-51.

20. Sidelnykova L.P. (2016). Asymmetries of formation of resources of the pension fund of Ukraine. Naukovy'j visny'k Xersons'kogo derzhavnogo universy'tetu. Vy'pusk 18. Chasty'na 2, 162-165. [in Ukrainian]

21.Social security tax. Poland KPMG. Retrieved from https://home.kpmg/xx/en/home/insights/2011/12/poland-other-taxes-levies.html

22. Spain - other taxes and levies. Spain. KPMG. Retrieved from https://home.kpmg/xx/en/home/insights/2011/12/spain-other-taxes-levies.html

23. Sweden payroll and tax overview. Global payroll. Retrieved from https://www.activpayroll.com/global-insights/sweden

24. The letter of the State Fiscal Service of Ukraine (2019). № 755/3ח।/99-99-17-03-14 from 16.04.2019.

25. Wolff B. (2005). Measuring tax burdens in Europe. Center for European Integration Studies, 44.

26. Zakharkin, O., Basantsov, I., Myroshnychenko, lu. \& Shcherbachenko, V. (2019) Analysis of the innovative development directions for industrial enterprises, Espacios, 40 (27), 16-25. Retrieved from http://www.revistaespacios.com/a19v40n27/a19v40n27p16.pdf

27. Zipfel, F. (2012). The impact of tax systems on economic growth in Europe. An overview. Deutsche Bank. 12 p.

28. Žul'ová, J., \& Kundrát, I. (2020). Service of documents in employment relationships during the employee quarantine. Central European Journal of Labor Law and Personnel Management, 3 (1), 74-84. http://doi.org/10.33382/cejllpm.2020.04.06 